\title{
Experimental and analytical behavior of strengthened reinforced concrete columns with steel angles and strips
}

\author{
Essam S. Khalifa $\cdot$ Sherif H. Al-Tersawy
}

Received: 31 May 2013/Accepted: 4 June 2014/Published online: 19 June 2014

(C) The Author(s) 2014. This article is published with open access at Springerlink.com

\begin{abstract}
The need of strengthening reinforced concrete columns, due to loss of strength and/or stiffness, is an essential requirement due to variation of the loads and environmental conditions applied on these columns. Steel jackets around the reinforced concrete (RC) columns are usually made by means of steel plates covering all over the column surface area. For the value of engineering purposes, another technique was developed using steel angles at the corners of the RC columns connected with discrete steel strips. In this paper, an experimental program is designed to evaluate the improvement in loadcarrying capacity, stiffness and ductility of strengthened $\mathrm{RC}$ columns, concomitant with steel angles and strips. Despite of prevailing a substantially increased loading capacity and strength a pronounced enhancement in ductility and stiffness has been reported. A need for experimental test results with low value of concrete strength to mimic the local old-age structures condition that required strengthening in local countries. Seven columns specimens are tested to evaluate the strength improvement provided by steel strengthening of columns. The method of strengthened steel angles with strips is compared with another strengthening technique. This technique includes connected and unconnected steel-casing specimens. The observed experimental results describe load-shortening curves, horizontal strains in stirrups and steel strips, as well as description of failure mode. The extra-confinement pressure, due to existence of steel cage, of the strengthened RC column can be also observed from experimental results. The code provisions that predict the load-carrying
\end{abstract}

E. S. Khalifa $(\bowtie) \cdot$ S. H. Al-Tersawy

Higher Technological Institute, Tenth of Ramadan City, Egypt

e-mail: esamkhalifa@live.com capacity of the strengthened RC composite column has a discrepancy in the results. For this reason, an analytical model is developed in this paper to compare the code limit with experimental observed results. The proposed model accounts for the composite action for concrete confinement and enhancement of the local buckling of steel elements. This adopted model is simplified and applicable to practical design field. In this respect, the experimental results and those of the analytical model showed a good agreement.

Keywords Experimental $\cdot$ Composite $\cdot$ Steel strips $\cdot$ Steel casing $\cdot$ Strengthening $\cdot$ Analytical $\cdot$ RC columns

\section{Research significance}

This paper intended to perform an experimental investigation to examine the enhancement of strengthened RC columns, using steel angles and strips. The code provisions that predict the load-carrying capacity of the strengthened RC composite column has a discrepancy in the results. A need was required for experimental studies to compare the analytical model with the code limit. Thus, seven specimens have been developed to investigate the load-carrying capacity, stiffness and strength enhancement of the strengthened columns. The experimental results quietly addressed the load-shortening curve, horizontal strains in stirrups and strips. A comparison between strengthened RC column with steel angles and strips with those columns strengthened with steel-casing was developed. The obtained experimental results were compared with the code limit and then an analytical model was developed in order to monitor the studied strengthened column performance. 


\section{Introduction}

Strengthening of reinforced concrete columns using steel angles and strips is becoming a widely accepted technology in the construction industry. The composite concrete-steel materials, as exhibiting high stiffness, appeared as innovated solutions adapted for strengthening and repair of the structural columns. These concrete-steel composite materials are usually used as non-unidirectional material such as carbon fibers. The best benefit of using steel angles with strips, in strengthening of RC columns, is not only for increasing the load-carrying capacity but also for the pronounced effect on the column stiffness and ductility. Strengthening the concrete structures, to resist higher design loads correct deterioration-related damage that is usually achieved on using steel angles with strips. The need is necessary for strengthening reinforced concrete columns due to variation of the loads and environmental conditions applied on these columns. In the last three decades, there has been a widespread in the number and type of strengthening columns. Strengthening by using steel elements has been observed with several experimental studies (Frangou et al. 1995; Montuori and Piluso 2009; Li and Gong 2009; Papia et al. 1988; Ramirez et al. 1997; Campione and Minafo 2010; Adam et al. 2008). Many theoretical models have been conducted to investigate the behavior of confined and unconfined axially loaded reinforced concrete columns (Mander et al. 1988; Campione 2008). Theoretical studies (Critek 2001; Barga et al. 2006; Adam et al. 2009) focused on the behavior of strengthened reinforced concrete composite columns subjected to failure. However, most of the studies addressed separately the increase in load carrying capacity to the confinement of concrete core or to the composite action if angels are directly loaded. Meanwhile, recent analytical models for strengthened reinforced concrete columns were developed and account for this composite action, using steel angles and strips (Badalamenti et al. 2010; Campione 2012). These studies examined some of the existing models to calculate the load-carrying capacity of strengthened columns.

The designed requirements for composite, reinforced concrete columns are also addressed with many code provisions (The Egyptian Code of Practice for Design and Construction of Concrete Structures (ECP203) 2007; Eurocode 4 1994; American Institute of Steel Construction 1994). The code provisions that predict the load-carrying capacity of the strengthened RC composite column have discrepancies in the results. This needs to perform experimental studies to be compared with the analytical models and code limits. The range of variation of minimum and maximum amount of steel angles, with reference to concrete core, is that given by Eurocode 4 (1994). A need for experimental test results with low value of concrete strength to mimic the local old-age structures condition that required strengthening in local countries. In this paper, seven specimens are developed to study the load-carrying capacity, stiffness and strength enhancement of the strengthened columns. These samples are composed of a control specimen and four specimens with different configurations of strengthened RC columns using steel angles and strips. The remaining two samples represent connected and non-connected full steel casing that are used to compare the different strengthening methods. The predicted experimental results reasonably described the load-shortening curves of the strengthened RC columns and horizontal strains in stirrups and strips. A proposed analytical model is also developed to compare the code limit with the experimental observed results. The proposed model accounts for the composite action for concrete confinement and enhancement of the local buckling of steel elements. This adopted model is simplified and applicable to practical design field. This would then monitor the studied strengthened column performance. A good agreement was obtained on comparing the experimental observed results with those of the analytical model.

\section{Experimental study and test program}

Seven specimens were conducted to study the strengthened RC columns, using different varieties of composite steelcasing configurations. These specimens included a control using reinforced concrete column without strengthening. The strengthened reinforced concrete columns included two series; the first series contained four strengthened columns with steel angles and strips, while the second one contained two columns strengthened by steel-casing. The total column length was developed in the seven samples was $1,000 \mathrm{~mm}$. The samples were casted and cured in the laboratories of the Higher Technological Institute (HTI), whereas the test program was conducted in the laboratory of National Center for Research, Construction and Housing (HBRC). The details of each specimen with respect to material properties and experimental program are described in the following subsection.

\section{Tested columns fabrication}

The adopted reinforced concrete column cross section and reinforcement details were carried out according to requirements of the design code (The Egyptian Code of Practice for Design and Construction of Concrete Structures (ECP203) 2007) as shown in Table 1. Figure 1 shows the control specimens with longitudinal reinforcement of grade 36. Each column is consisted of four bars $(12 \mathrm{~mm}$ 
Table 1 Test parameters and strengthened column details

\begin{tabular}{|c|c|c|c|c|c|c|c|c|}
\hline \multirow[t]{2}{*}{ Series } & \multirow{2}{*}{$\begin{array}{l}\text { Column } \\
\text { code }\end{array}$} & \multicolumn{2}{|c|}{ Strengthening System } & \multicolumn{2}{|l|}{ Reinforcement } & \multicolumn{3}{|c|}{ Strengthening system details } \\
\hline & & $\begin{array}{l}\text { Steel angles } \\
\text { with strips }\end{array}$ & Steel-casing & Longitudinal & Stirrups & $\begin{array}{l}\text { Steel angles } \\
(\mathrm{mm})\end{array}$ & $\begin{array}{l}\text { Strip thickness } \\
(\mathrm{mm})\end{array}$ & $\begin{array}{l}\text { Plate thickness } \\
(\mathrm{mm})\end{array}$ \\
\hline \multirow[t]{5}{*}{ A } & Control & - & - & $4 \mathrm{~T} 12$ & R8-200 & - & - & - \\
\hline & CS1 & Applicable & - & $4 \mathrm{~T} 12$ & R8-200 & $40 \times 5$ & 5 & - \\
\hline & $\mathrm{CS} 2$ & Applicable & - & $4 \mathrm{~T} 12$ & $\mathrm{R} 8-200$ & $40 \times 6$ & 6 & - \\
\hline & $\mathrm{CS} 3$ & Applicable & - & $4 \mathrm{~T} 12$ & R8-200 & $50 \times 5$ & 5 & - \\
\hline & $\mathrm{CS} 4$ & Applicable & - & $4 \mathrm{~T} 12$ & R8-200 & $50 \times 6$ & 6 & - \\
\hline \multirow[t]{2}{*}{ B } & $\mathrm{CF} 1$ & - & Applicable & $4 \mathrm{~T} 12$ & R8-200 & - & - & 3 \\
\hline & $\mathrm{CF} 2$ & - & Applicable & $4 \mathrm{~T} 12$ & R8-200 & - & - & 3 \\
\hline
\end{tabular}

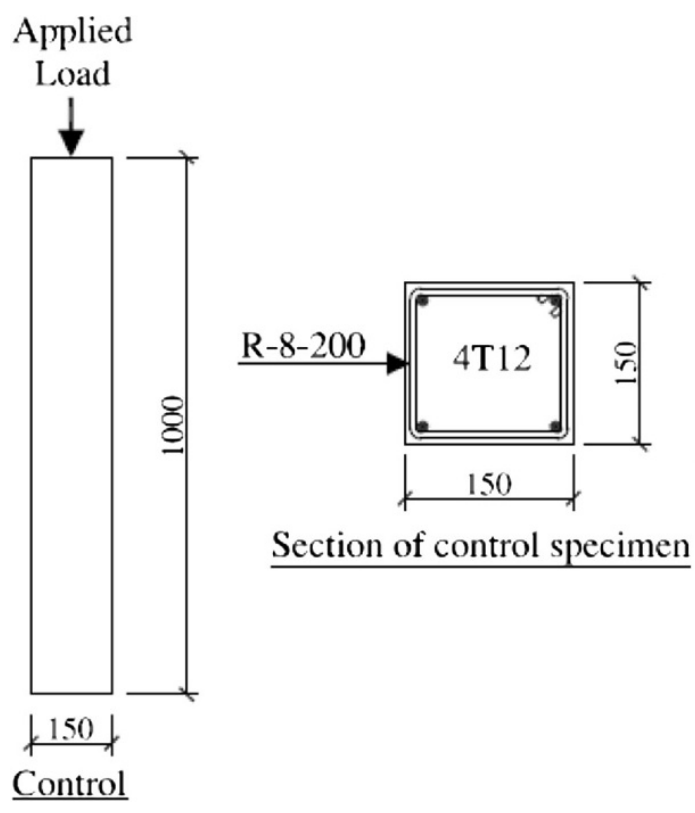

Fig. 1 Concrete dimension and reinforcement details of the control column specimen

diameter) and horizontal stirrups ( $8 \mathrm{~mm}$ diameter) placed each $200 \mathrm{~mm}$ of steel grade 24, as per ECP-203 (The Egyptian Code of Practice for Design and Construction of Concrete Structures (ECP203) 2007) description. The concrete cover of longitudinal reinforcement is $15 \mathrm{~mm}$. Horizontal and longitudinal reinforcement were placed with identical values for the seven specimens in order to enable comparison between the adopted strengthened column results. These longitudinal and horizontal bars were instrumented with strain gauge just prior to casting the concrete. The column specimens were casted in steel formwork at the casting yard under normal production condition. Steel column cage is used as formwork of RC column specimens. This condition is identical to strengthened column in site with grouting between concrete column and steel cage. Four RC column specimens, of the series (A), were strengthened with steel plates and strips as shown in Fig. 2. Series (B) represents strengthened column specimen by steel-casing columns connected and nonconnected as shown in Fig. 3. The strengthened reinforced concrete column specimen encoded CS1 before testing performance is shown in Fig. 4. Connected columns of series (B) were done by use of staggered four dowels at each face to avoid column cross section weakness.

\section{Test setup}

Test performance was carried out using steel angles, strips and plates as per specifications to ensure quality and excellence. The steel plates yield stress experimental measured value is $244 \mathrm{MPa}$. The test setup machine could conduct the experimental results of the strengthened RC columns shown in Fig. 5. Typical tests were carried out according to the methodology and specifications. A thick steel plate was used at tested column ends of each specimen with concrete grouting to ensure that the load was simultaneously applied on the composite steel and RC composite section. The steel-casing was manufactured prior casting the RC columns. Tests were performed to predict the tensile behavior of the steel reinforcement and steel plates used for strengthening compartments. The yield stress of the longitudinal reinforcement is $368.5 \mathrm{MPa}$ with a percentage of elongation equaling $12.8 \%$. The yield stress of the stirrups reinforcement is $245 \mathrm{MPa}$, with percentage of elongation $21.6 \%$. The design of reinforced concrete columns were carried out to satisfy the requirements of ECP-203 (2007).

The concrete used for the columns was a normal weight concrete of 28-day average compressive cube strength of value $32.8 \mathrm{MPa}$. Mix proportions were $3.9 \mathrm{kN} / \mathrm{m}^{3}$ ordinary Portland cement, $6.4 \mathrm{kN} / \mathrm{m}^{3}$ sand from natural sources, $12.9 \mathrm{kN} / \mathrm{m}^{3}$ crushed limestone $(12.5 \mathrm{~mm}$ maximum nominal size) and $1.62 \mathrm{kN} / \mathrm{m}^{3}$ of water. All RC columns were casted in the same mould, at the same time and from the same batch. Concrete was compacted in the form using a table vibrator, followed by water curing and covering with 
Fig. 2 Concrete dimensions and reinforcement details of strengthened RC columns with steel angles and strips
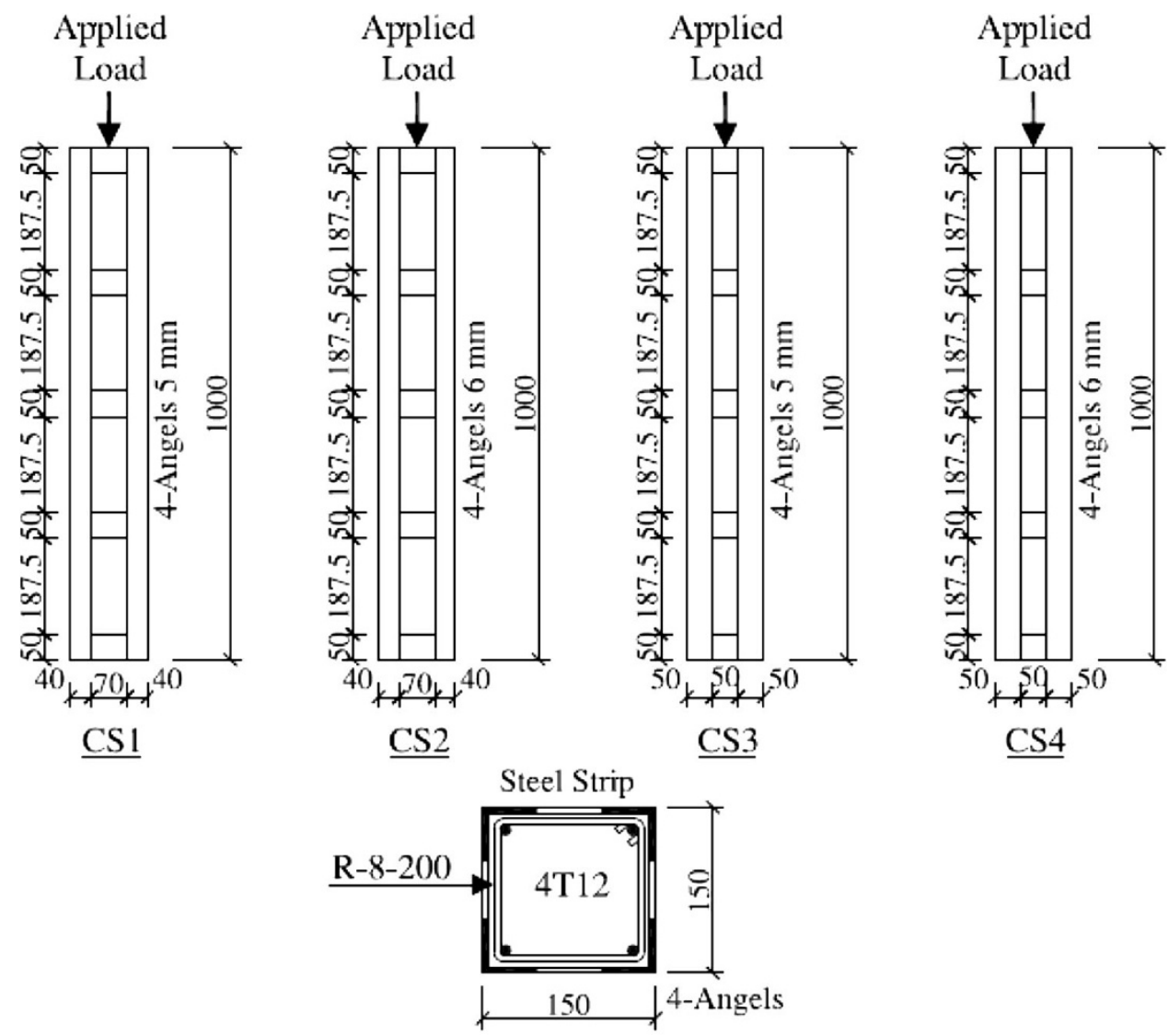

Typical Section

Fig. 3 Strengthened RC columns with connected and non-connected steel-casing

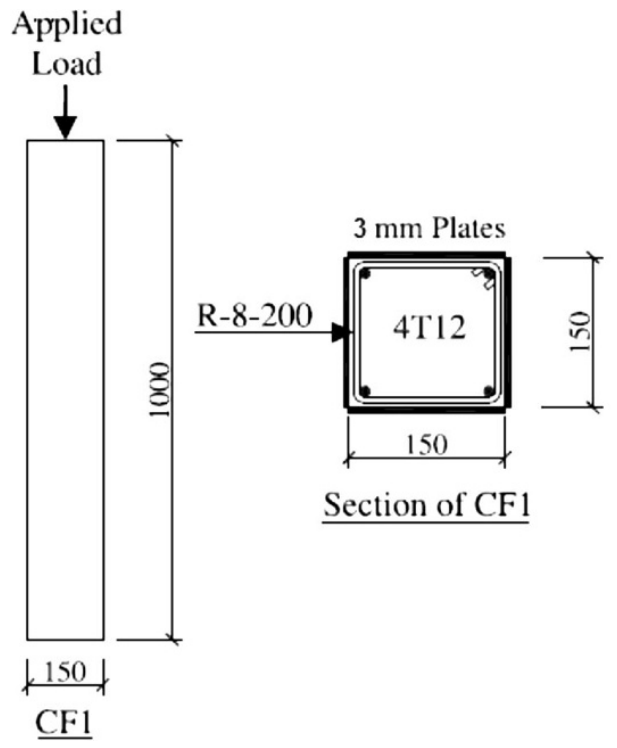

polyethylene sheeting for 1 week. The concrete cubes and split cylinders were tested on the same day of column testing, in order to provide values of the concrete characteristic strength $f_{\text {cu }}$, cylinder strength $f_{\mathrm{c}}$ and splitting tensile strength.
Instrumentation and test procedure

The concrete compressive strength for tested columns is considered as the average strength of at least three cylinders representing the column. The average concrete 


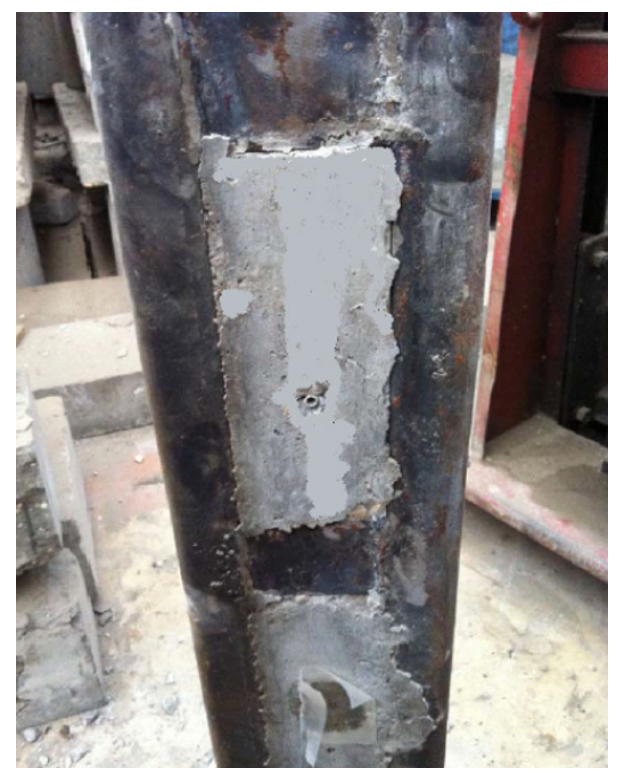

Fig. 4 Strengthened RC column specimen CS1 with steel angles and strips

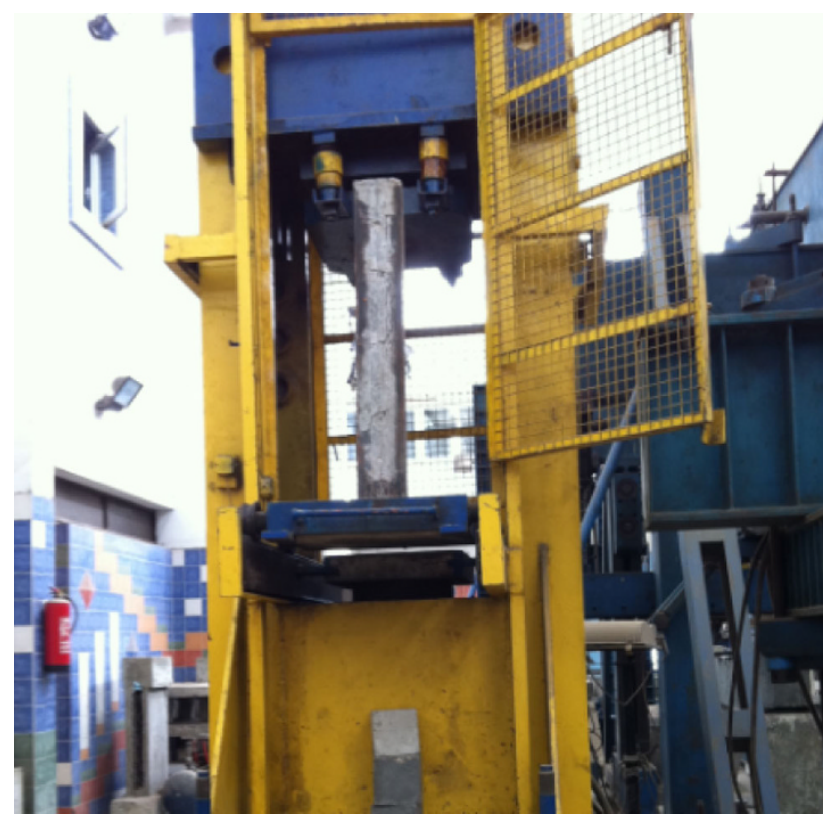

Fig. 5 Experimental testing machine of strengthened columns

cylinder compressive strength is $26.24 \mathrm{MPa}$ to mimic a low value of strength-case of study for old-age structures in the local countries. The testing machine of strengthened RC column with steel angles and strips is shown in Fig. 6. The mixing of column's concrete was worked out according to applied code and specifications procedure. Readings were extracted from strain gauges embedded in the concrete inside the column core, longitudinal main steel and longitudinal strain readings from steel angles and strips. The

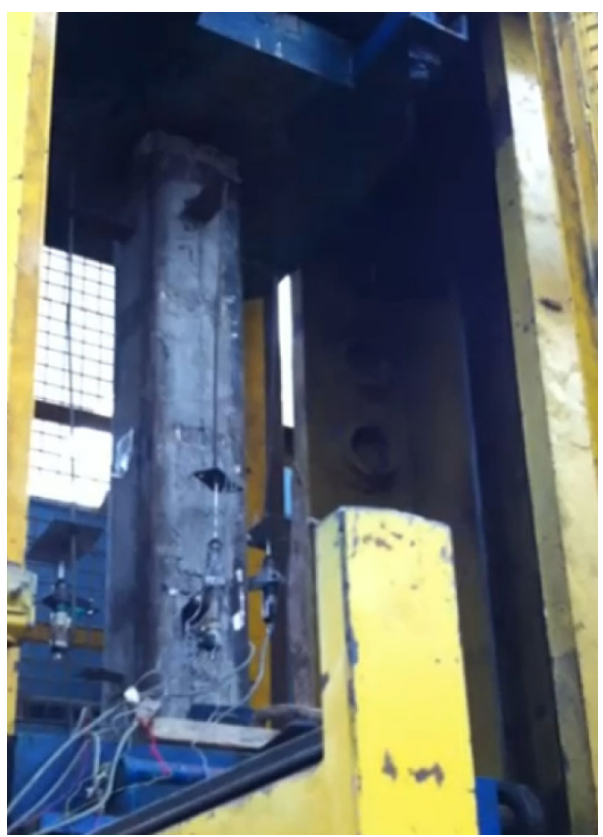

Fig. 6 Instrument for testing the strengthened RC columns with steel angles and strips

recorded readings are considered at column mid-height during testing of strengthened columns. LVDT instruments were also used, at column mid-height, to measure longitudinal shortening of the tested columns.

\section{Experimental work-results and discussion}

The experimental program enables testing axially loaded columns on strengthened reinforced concrete columns. Statically axial loading was applied for testing the columns up to failure. The experimental results included loadshortening curves for different column types, load-lateral strain at external steel strips and internal stirrup, at the same level of steel strips as well as at mid-height of the strengthened column. Failure modes were also predicted and discussed in conjunction with the experimental results. In the next subsections, the experimental work-results have been presented and discussed. The conclusion predicted for the experimental results of strengthened reinforced concrete columns, as compared with the control specimen, is shown in Table 2.

Axial load-shortening responses and modes of failure

The load-shortening curves for the control specimen with strengthened column specimens CS1 up to CS4 are shown in Fig. 7. On the other hand, the load-shortening curves of the two strengthened columns with full coverage column area steel plates $\mathrm{CF} 1$ and $\mathrm{CF} 2$ and the control specimen are 
Table 2 Summary of experimental results for strengthened and non-strengthened columns

\begin{tabular}{llllll}
\hline Specimens & Failure load $(\mathrm{kN})$ & Failure type & $\begin{array}{l}\text { Maximum column } \\
\text { shortening }(\mathrm{mm})\end{array}$ & $\begin{array}{l}\text { Maximum strain } \\
\text { in steel strips }\end{array}$ & $\begin{array}{l}\text { Maximum strain in } \\
\text { stirrups at level } \\
\text { of steel strips }\end{array}$ \\
\hline Control & 495.5 & Crushing of concrete & 0.90 & - & 0.0012 \\
CS1 & 676.2 & Concrete splitting out & 1.85 & 0.0037 & 0.0028 \\
CS2 & 789.5 & Concrete splitting out & 2.35 & 0.0048 & 0.0039 \\
CS3 & 730.8 & Concrete splitting out & 2.04 & 0.0041 & 0.0034 \\
CS4 & 821.3 & Concrete splitting out & 2.67 & 0.0055 & 0.0043 \\
CF1 & 1053.98 & Steel plate buckling & 4.1 & 0.0086 & 0.0069 \\
CF2 & 1149.4 & Steel plate buckling (between dowels) & 4.9 & 0.0103 & 0.0086 \\
\hline
\end{tabular}

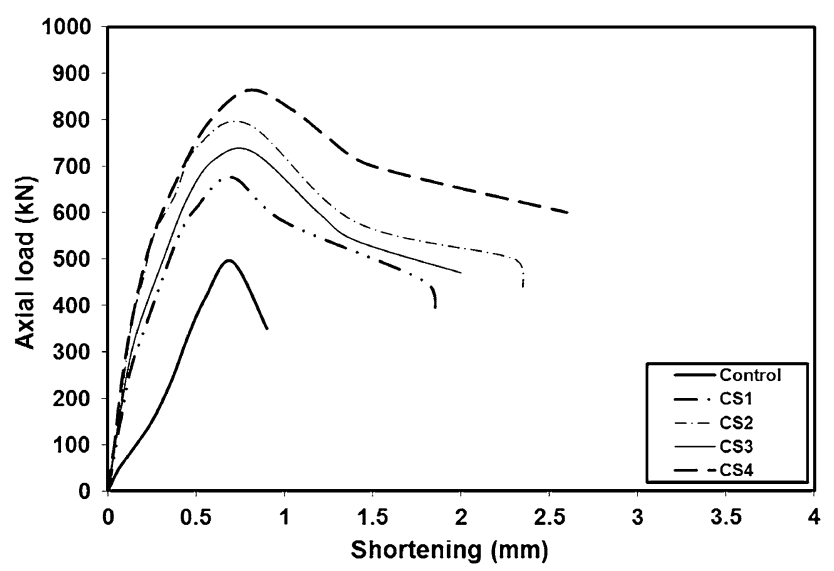

Fig. 7 Experimental results of load-shortening curves of strengthened columns using steel angles with strips

shown in Fig. 8. The column shortening was measured by LVDTs instruments while the longitudinal strain was measured by strain gauges in the reinforcement steel and inner concrete core. The strain gauges are well contact to steel-casing to measure the longitudinal and transverse strains for specimens $\mathrm{CF} 1$ and $\mathrm{CF} 4$. The results of the columns tested subjected to pure axial load showed that peak load became reduced fairly rapidly. Near initial loading, all the curves exhibited nearly linear-elastic parts of pre-crushing stages. The increase in the initial stiffness, for the strengthened columns, is due to improvement of the existence of steel angles and strips. The strengthened samples showed higher steady-state load shortening performances than the non-strengthened control specimens. Enhancement in the load carrying capacity of strengthened columns was mainly due to improvement in the strength of the confined concrete. It was also conducted that using the steel-casing, the effective moment of inertia is increased and thus ductility demand will also be increased.

Figure 7 shows that increased ultimate load capacities $\left(P_{\mathrm{u}}\right)$ 676.2, 789.5, 730.8 and $821.3 \mathrm{kN}$ were reached respectively for CS1, CS2, CS3 and CS4, as compared to

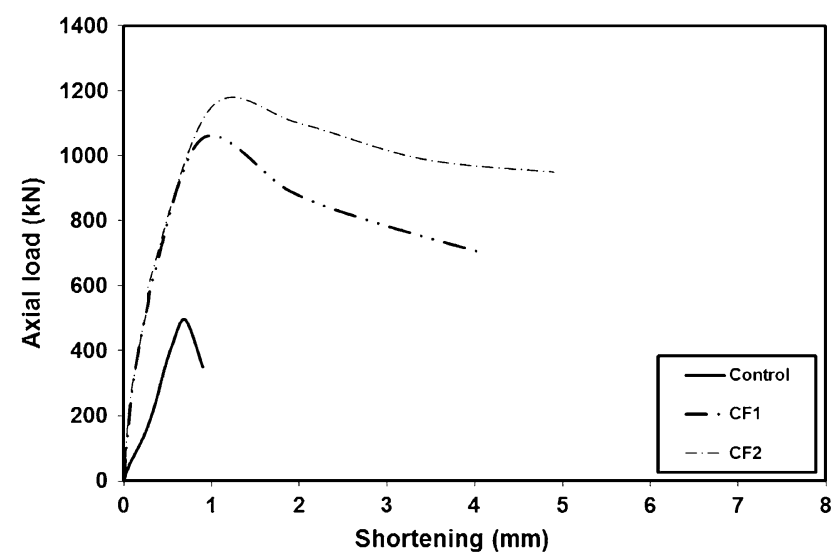

Fig. 8 Experimental results of load-shortening curves of strengthened columns using steel-casing

$495.5 \mathrm{kN}$ of the control column specimen. Figure 8 show that increased capacities $P_{\mathrm{u}}$ of $1,053.98,1,149.4 \mathrm{kN}$ were reached for $\mathrm{CF} 1$ and $\mathrm{CF} 2$, respectively, compared to $495.5 \mathrm{kN}$ of the control column specimen. Comparison between the two strengthened columns, using angles $40 \times 5 \mathrm{~mm}(\mathrm{CS} 1)$ and $40 \times 6 \mathrm{~mm}$ (CS2), shows an increase of the loading capacity by about $17 \%$. For the strengthening of column, using angles $50 \times 5 \mathrm{~mm}(\mathrm{CS} 3)$ and $50 \times 6 \mathrm{~mm}$ (CS4), shows an increase of the loadcarrying capacity by about $12 \%$. The load-shortening curve of specimen CS4 is more smooth, ductile and stable than the curve of specimen CS3. It could be concluded from the experimental results that the percentage increase in load-carrying capacities reached 36, 59, 48 and $66 \%$ for CS1, CS2, CS3 and CS4, respectively, as compared to the control column specimen. On the other hand, the percentage increase in load carrying capacity was approximately doubled in specimen $\mathrm{CF} 1$, as compared to the control specimen. With using connected case with dowels for sample CF2, the load-carrying capacity was increased by $9 \%$. As shown from Fig. 8, the load-shortening curve of sample CF2 is much flat and sustains higher shortening 


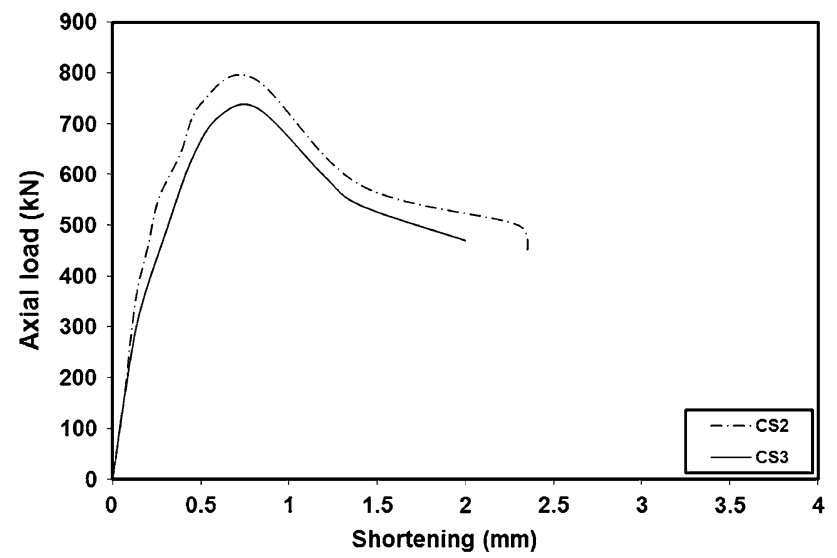

Fig. 9 Comparison between experimental observed load-shortening curves of specimens CS2 and CS3

value. In specimen $\mathrm{CF} 2$, the use of dowels delaying the steel plates local buckling that produced more confined concrete. This increase in the load-carrying capacity acted in the connected column than in the unconnected one. It is evident that strengthened column of series A as well as of series B exhibited different elastic initial stiffness as shown in Figs. 7 and 8. This might be attributed to increase of not only the strengthened column load-carrying capacity, but also in the column initial stiffness.

Load-shortening curves for the specimens CS2 and CS3 are shown in Fig. 9. The specimen CS2 is strengthened with an angle dimension of $40 \times 6 \mathrm{~mm}$ and $6 \mathrm{~mm}$ strip thickness, while specimen CS3 is strengthened with an angle of $50 \times 6 \mathrm{~mm}$ with $5 \mathrm{~mm}$ strip thickness. The cross sectional area of steel angles of the strengthened specimen CS2 is lower than the cross sectional area of steel angles of specimen CS3 by about $4 \%$. The predicted load carryingcapacity of sample CS2 is higher than that of sample CS3 by $8 \%$, regardless small angle area. This increase in load capacity and ductility demand is attributed to using thicker strips and therefore it developed much concrete confinement produced higher load-carrying capacity. It can be concluded that the increase of strip thickness and/or reduction on strips spacing is much effective than increase of steel angle dimensions. Figure 10 shows the loadshortening curve of specimen CF1, compared to CS4. The load-carrying capacity of CF1 is much higher than that of CS4 by about $28 \%$. Thus, the strengthened columns in series B can sustain higher shortening values than strengthened columns of series A. This is due to the delay of concrete splitting out after crushing of concrete, and therefore, realistic increase in the load-carrying capacity can be achieved.

The failure modes of the columns, which are of considerable importance, are primarily associated with steel yielding, steel local buckling and concrete crushing,

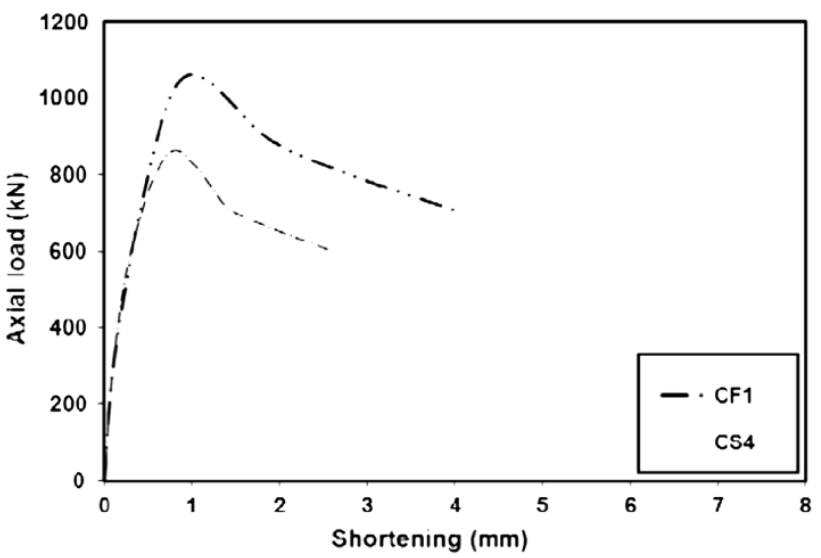

Fig. 10 Comparison between experimental observed load-shortening curves of different strengthening methods for specimens CS4 and CF1

monitored for a selection of test specimens. The concrete crushing that occurs at failure load causes a significant redistribution if a stress acts on the steel casing. This redistribution then promotes local buckling of steel, illustrated by erratic behavior of each of the gauges, after the peak load is reached. The control specimen failure mode is a typical compression failure of the reinforced concrete column. Strengthening of reinforced concrete columns using steel angles with strips and mode of failure is shown in Fig. 11. It has to be observed that the column failure occurs when the steel cage is no longer to confine the concrete. The failure occurs when the steel cage yields and concrete between the strips is splitting out. This failure mode occurred in series group A. In series B, a more steady failure mode of specimens $\mathrm{CF} 1$ and $\mathrm{CF} 2$, due to the exiting of steel-casing, prevents the concrete from splitting out. The failure occurred when the steel-casing suffered from large deformation due to its local buckling as shown in Fig. 12. The connected specimen (CF2) can sustain higher load-carrying capacity than non-connected one (CF1). Delay of steel-casing buckled, between anchors, occurred due to connection with RC column and thus higher loadcarrying capacity could be obtained.

\section{Load-lateral strain response}

The load-lateral strain results provide very useful information on lateral stiffness, yielding and failure mechanism of the strengthened columns. Figure 13 shows load-steel strips strain relations for the strengthened columns CS1 up to CS4 exhibiting maximum load-carrying capacity. Figure 14 shows load-stirrups strain relationship for the strengthened column CS1 up to CS4 with control specimen. As shown from Figs. 13 and 14, all columns show similar pre-crushing load-strain response. The measured 


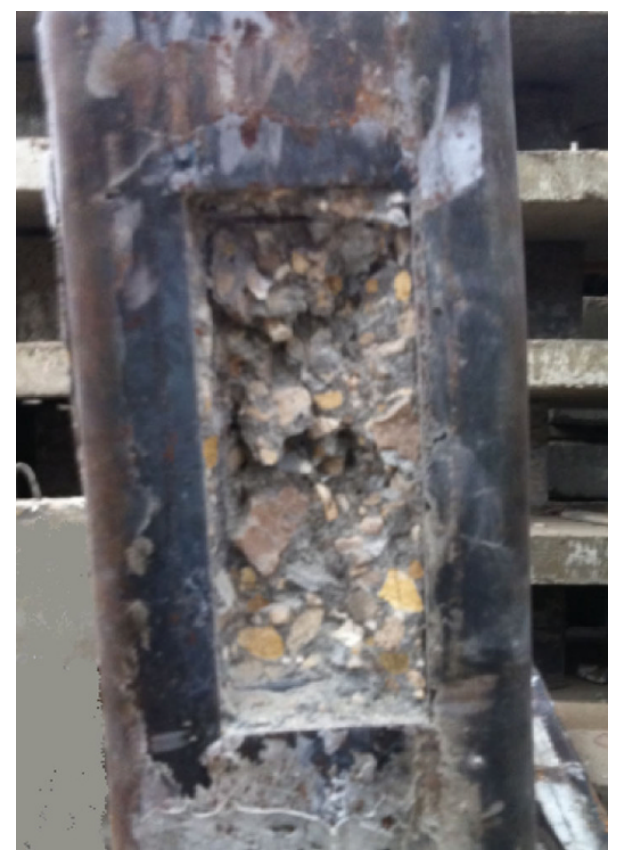

Fig. 11 Typical mode of failure for strengthened RC column using steel angles and strips

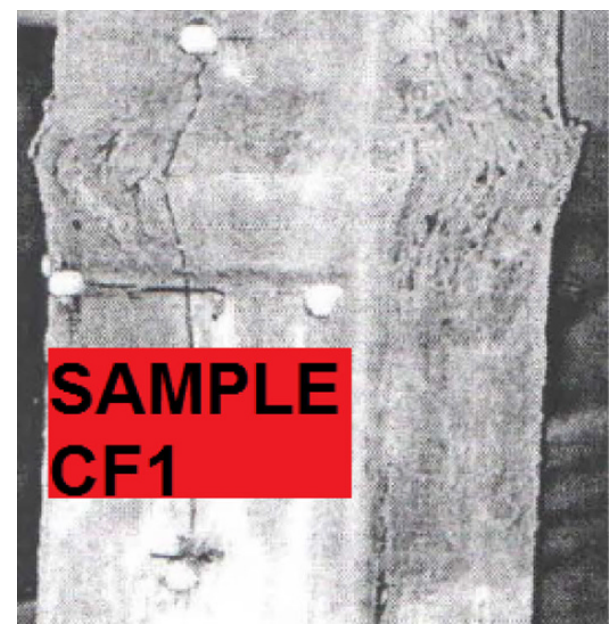

Fig. 12 Typical mode of failure for strengthened RC columns using steel-casing

stirrup strain is at the same level beyond the steel strip, at the strengthened column mid-height. It is obvious that all tension reinforcement yielded at loads higher than the control column (yield strain of reinforcement is 0.0012). It is obvious from Fig. 14 that the strain in the stirrup for the control specimen behaves as brittle manner. This small ductility is due to typical compression failure of the control specimen. On the other hand, the stirrup strain of the other strengthened columns behaves as ductile curve due to stiffening action of the steel strip at the same level of stirrup. The stiffening action of steel strip and angles

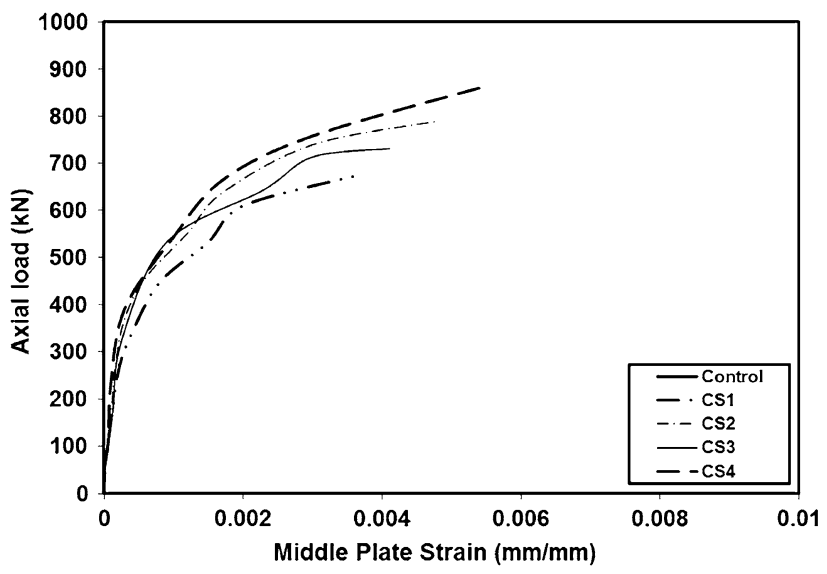

Fig. 13 Load-lateral strain relation up to maximum load at middle steel strip for strengthened columns with angles and strips

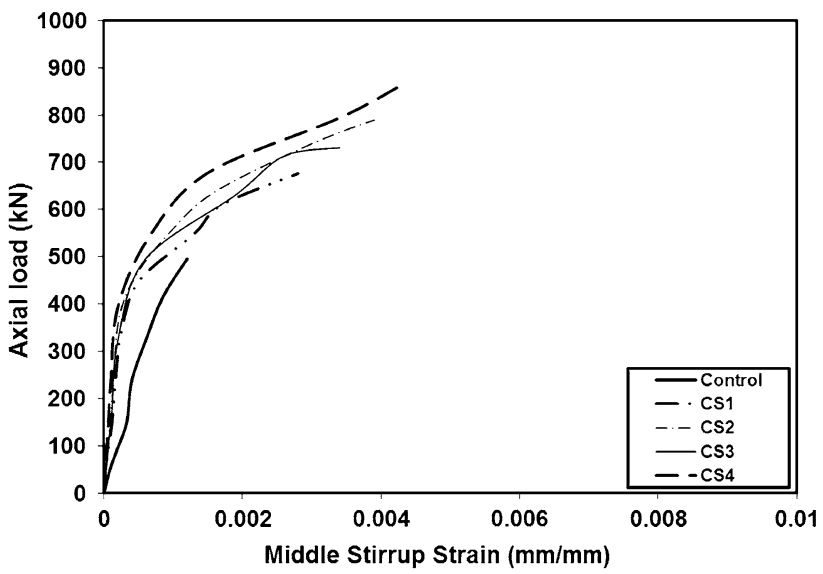

Fig. 14 Load-lateral strain relation up to maximum load at middle stirrup for strengthened columns with angles and strips

enhanced the confined concrete strength. In this case, delay in the sudden compression failure of the columns occurs. The confinement pressure of stirrups can be obverted from load-lateral strain curve of control specimen. Extra-confinement of strengthened columns can be observed through the experimental results, as shown in Fig. 14. With increasing the strip thickness, increasing the confinement strength and the strip in such a case can achieve extra strain. Comparing the results of load-strain of the strengthened column specimen CS1 with CS4 shows higher load-carrying capacity, yield at higher loads and more ductile smooth curve. Increasing of strip thickness makes more confinement of concrete and yield of the strip occurred at higher load values. This lead to delay of the concrete splitting out, and higher load values can be carried out as shown in Fig. 13. It can be concluded from Fig. 14 that strengthened column load gradient is greater than that of the control specimen due to a marked increase in initial stiffness. 


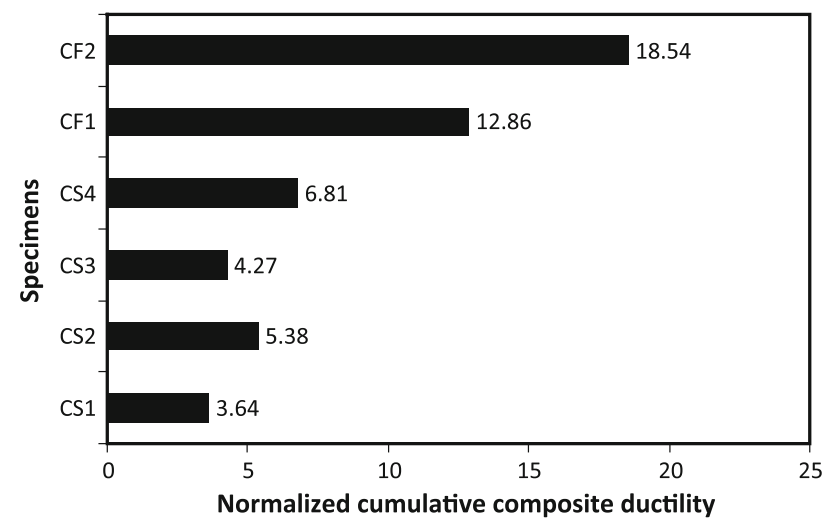

Fig. 15 Normalized cumulative composite ductility of different specimens

\section{Column-ductility demand and stiffness}

Strengthened column ductility is one of the great benefits of strengthening reinforced concrete columns. The column ductility demand is used in this case as qualitative measure. In this paper, the cumulative composite ductility $C_{\mathrm{m}}$ at any point (i) is given as summation function of axial load at level (i), $P_{\mathrm{i}}$, and the axial load at a previous point $(\mathrm{i}-1)$ $P_{\mathrm{i}-1}$, relative to the difference between longitudinal shortening between two points, as follows:

$C_{m}=\sum_{\mathrm{i}=1}^{n} \frac{P_{\mathrm{i}-1}+P_{\mathrm{i}}}{2\left(D_{\mathrm{vi}}-D_{\mathrm{v}(\mathrm{i}-1)}\right)}$

where $D_{\mathrm{vi}}$ and $D_{\mathrm{v}(\mathrm{i}-1)}$ are the longitudinal column shortening at points (i) and (i -1$)$, respectively. A twenty points are used, in this study, to calculate the $C_{\mathrm{m}}$ value. The normalized cumulative composite ductility $\left(C_{\mathrm{m}}\right.$ (Strengthened) can be measured as a factor of strengthened column divided by control specimen $C_{\mathrm{m} \text { (Control) }}$, as shown in Fig. 15 .

For the design purpose, the required gain from the strengthened columns not only increase ductility demand but also is required sometimes to increase the column stiffness capacity. The composite strengthened column cumulative stiffness at point (i) $S_{\mathrm{m}}$ is given as a function of axial load $P_{\mathrm{i}}$ and longitudinal displacement $D_{\mathrm{vi}}$ at the same point as follows:

$S_{\mathrm{m}}=\sum_{\mathrm{i}=1}^{\mathrm{n}} \frac{P_{\mathrm{i}}}{D_{\mathrm{i}}}$

A twenty points are used, in this study, to calculate the $S_{\mathrm{m}}$ value. The normalized cumulative composite stiffness $\left(S_{\mathrm{m} \text { (Strengthened) }}\right)$ can be measured as a factor for strengthened column divided by control specimen $S_{\mathrm{m} \text { (Control) }}$, as shown in Fig. 16.

It is evident from Fig. 15 that a remarkable increase $(89 \%)$ is obtained in the ductility measure of the

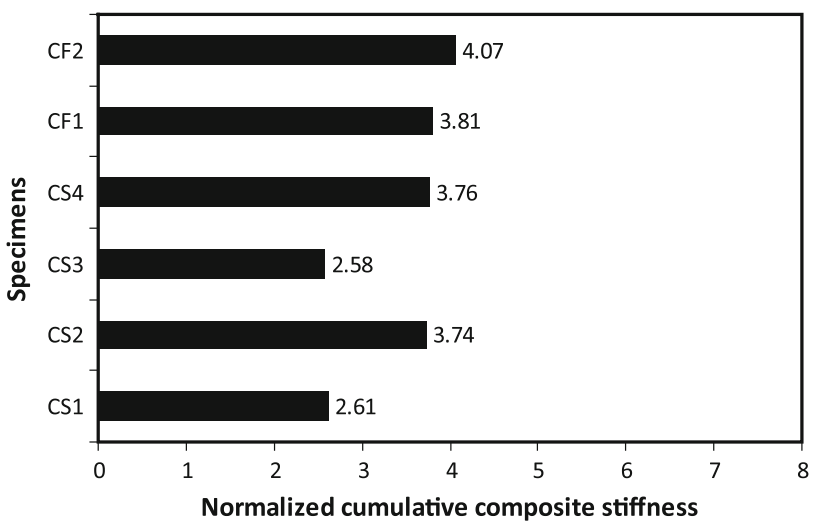

Fig. 16 Normalized cumulative composite stiffness of different specimens

strengthened columns using full coverage area steel plated $\mathrm{CF} 1$, as compared with specimen CS4. It is also obvious that the normalized cumulative stiffness of the strengthened column specimen CS4 is increased by about $87 \%$ than specimen CS1. It can be noted that normalized cumulative stiffness of specimens CS1 and CS3 have the same values. Specimens CS2 and CS4 also have similar values as shown in Fig. 16. This indicates that the strip thickness and spacing have the major impact on the increase of cumulative stiffness. The dowel connected steel plates (specimen $\mathrm{CF} 2$ ) posses a much higher cumulative stiffness by about $7 \%$ than non-connected ones.

\section{Analytical model for prediction of load carrying capacity}

Buckling verification of steel angles

The case study of experimental observed square column strengthened by angles and strips can be analytically applied as shown in Fig. 17. The analytical models found in literature (Badalamenti et al. 2010; Campione 2012) for calculating the strength contribution of steel angles, adopted a loading application for continuous beam supported on axially loaded strips. These beams are considered as a load with the confinement pressure of the reinforced concrete column. In this case, the risk buckling occurring between the steel strips and the concrete will be splited out (Adam et al. 2009). The critical load $P_{\text {cr }}$ and critical stress $\sigma_{\mathrm{cr}}$ can be predicted (Campione 2012) as further shown in the following:

$P_{\mathrm{cr}}=8.47 \sqrt{E_{\mathrm{r}} t_{1}\left(\alpha L_{1}\right) \frac{3 S_{2} t_{2} E_{\mathrm{h}}}{b . S}} \quad($ in $\mathrm{kN})$
$\sigma_{\mathrm{cr}}=\frac{P_{\mathrm{cr}}}{2 L_{1} t_{1}} \quad$ (in MPa) 


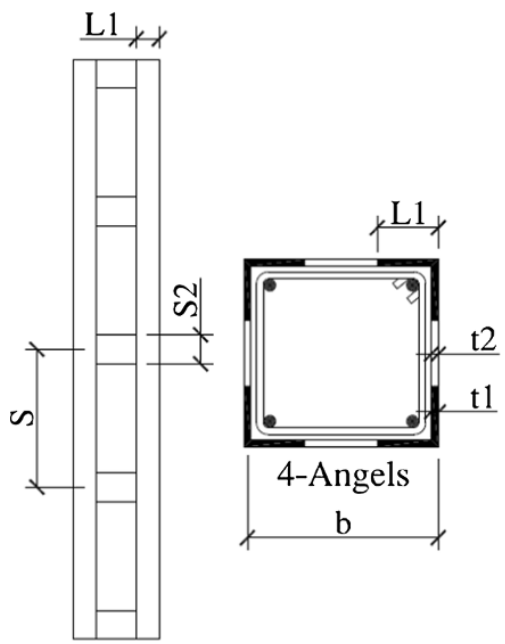

Fig. 17 Effective dimensions of strengthened columns by steel angles with strips

where $L_{1}$ and $t_{1}$ are the angle length and thickness, respectively. The spacing between the centerline of strips is noted as $S$ while the strips depth is noted as $S_{2}$. The value of $\alpha$ represents the equivalent rectangular cross section side and can be predicted from Fig. 18. The reduced modulus $E_{\mathrm{r}}$ (Papia et al. 1988) can be further expressed as follows:

$\frac{E_{\mathrm{r}}}{E_{\mathrm{s}}}=2.13\left(\frac{E_{\mathrm{h}}}{E_{\mathrm{s}}}\right)^{0.88}-4.11\left(\frac{E_{\mathrm{h}}}{E_{\mathrm{s}}}\right)^{2}$

where $E_{\mathrm{h}}$ the hardening modulus of steel angles and strips is, $E_{\mathrm{s}}$ is the modulus of elasticity of steel. Analytical expression is derived by Badalamenti et al. (2010) and Campione (2012) that can be applied only if the stiffness of strips is able to ensure that the critical length is equal to $S$ as shown in Fig. 19.

\section{Local buckling of steel plates}

For the concrete specimens $\mathrm{CF} 1$ and $\mathrm{CF} 2$, the code prevision (American Institute of Steel Construction 1994; American Concrete Institute (ACI) 1999) is applied to prevent local buckling occurring on the steel plates. The local buckling of the steel plates does not occur if the plate dimension $b$ for section to the plate thickness $t_{1}$ ratio does not exceed the code limitation and defined (American Institute of Steel Construction 1994; American Concrete Institute (ACI) 1999) as follows:

$\frac{b}{t_{1}} \leq \sqrt{\frac{3 E_{\mathrm{s}}}{f_{\mathrm{yl}}}}$

where $f_{\mathrm{yl}}$, is the yield stress of the steel plate in MPa. If the local buckling has occurred in the steel plate, a reduction of the plate area due to local buckling should be applied. In this case, the plate dimension $b$ should be reduced (Brain

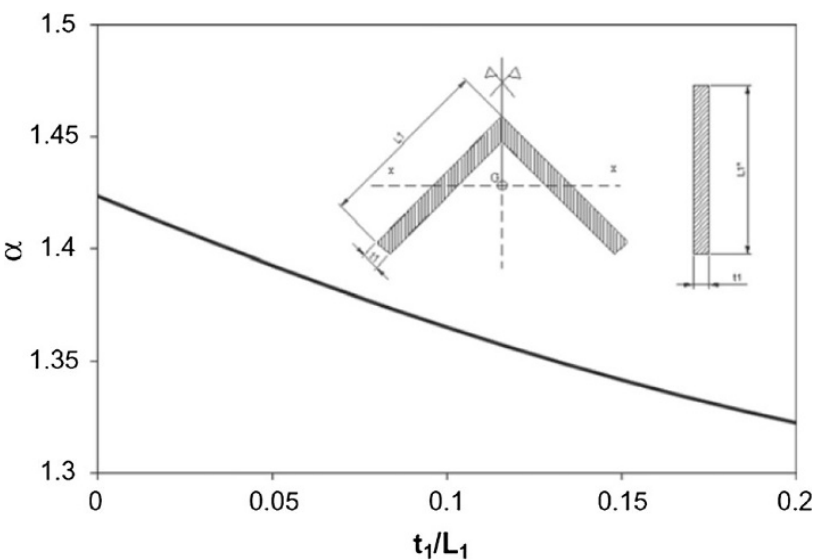

Fig. 18 Prediction of the value of $\alpha$ corresponding to $t_{1} / L_{1}$ (Badalamenti et al. 2010)

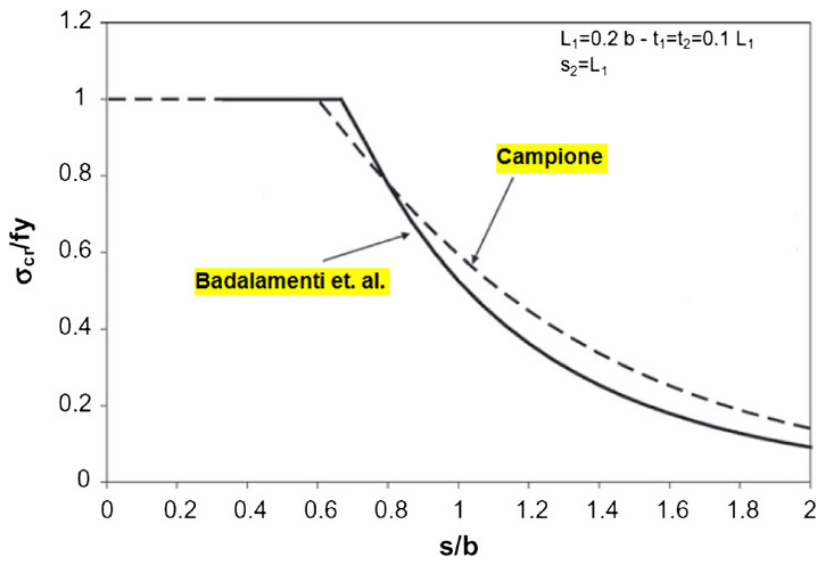

Fig. 19 Critical stress with $S / b$ relationships by Badalamenti et al. (2010) and Campione (2012)

2000) to $b_{\mathrm{e}}$, as shown in Fig. 20. The effective dimension considering local buckling of the steel-casing is shown in Fig. 20b for the case of axial load with minimum eccentricity. The ratio between the reduced dimensions of the buckled plate $b_{\mathrm{e}}$ to the original dimension of the steel plate $b$ can be expressed as:

$\frac{b_{\mathrm{e}}}{b} \leq \lambda \sqrt{\frac{f_{\mathrm{e}}}{f_{\mathrm{yl}}}}$

where the constant $(\lambda)$ can be predicted to account for best fit of the experimental results (Brain 2000) as 0.65. The local buckling stress $f_{\mathrm{e}}$ can then be calculated as follows:

$f_{\mathrm{e}}=\frac{K \pi^{2} E_{\mathrm{s}}}{12\left(1-v^{2}\right)(b / t)^{2}}$

The local buckling coefficient $(K)$ is taken as 10.31 for this case study (Brain 2000). 


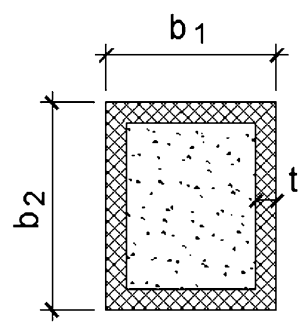

(a) Without Local Buckling

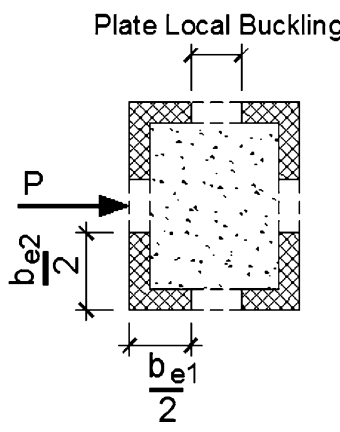

(b) With Local Buckling
Fig. 20 Effect of local buckling on the steel plates of steel-casing

Prediction of confined concrete strength

For the strengthened RC columns, the steel angles with strips developed a confinement effect for concrete as shown in Fig. 21. The confined compressive stress of concrete $f_{\mathrm{cc}}$ can be given as a function of unconfined compressive strength $f_{\mathrm{c}}$. According to load carrying capacity, it is obtained as the product of compressive strength of confined concrete for the square of the transverse cross section. In this case, the relation of confined compressive stress can be obtained ( $\mathrm{Li}$ and Gong 2009) as a function of equivalent confinement pressure $f_{l}$ as follows:

$\frac{f_{\mathrm{cc}}}{f_{\mathrm{c}}}=1+2.15\left(\frac{f_{1}}{f_{\mathrm{c}}}\right)$

$f_{1}=\frac{2 t_{2} S_{2} f_{\mathrm{yl}}}{S \cdot b}$

Another analytical model is proposed (Campione 2012) to account for the confined concrete compressive strength value due to strengthening of steel angles and strips. The relation between confined compressive strength and unconfined one can be given as:

$\frac{f_{\mathrm{cc}}}{f_{\mathrm{c}}}=1+4.74\left[\frac{f_{\mathrm{yl}}}{f_{\mathrm{c}}} \cdot \frac{t_{\mathrm{s}} S_{2}}{S \cdot b} \cdot e^{\left(-1.5 \frac{S}{b}\right)}\right]^{0.87}$

The stiffness per unit length of the strips $K_{\mathrm{s}}$ is highly effective on the confined strength of concrete. The presence of confinement pressure induced further buckling effect. The axial stiffness of steel strips can be evaluated as:

$K_{\mathrm{s}}=\frac{2 E_{\mathrm{s}} t_{2} S_{2}}{b}$

In this case, a correction factor for the confinement pressure should be applied to account for axial deformation of the strips and deformations of steel angles. To account for confined concrete compressive strength, the correction factor multiplier $K_{\mathrm{e}}$ can be expressed as:
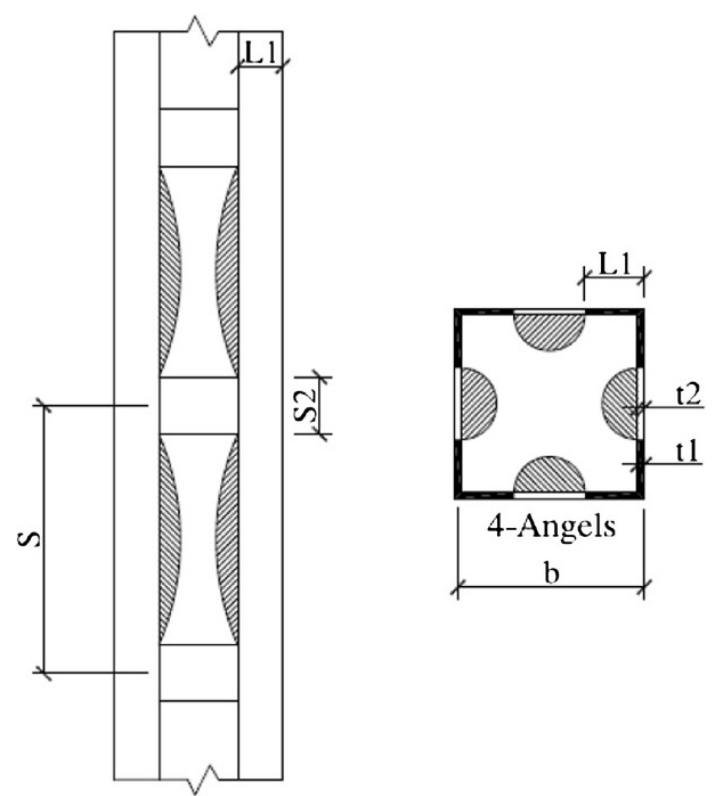

Fig. 21 Effective confinement pressure due to steel strips and angle

$K_{\mathrm{e}}=\left(1-\frac{\left(b-2 L_{1}\right)^{2}}{b^{2}}\right)\left(1-\frac{S-0.5 S_{2}-L_{1}}{2 b}\right)^{2}$

Prediction of load-carrying capacity of strengthened column

The predicted load carrying capacity of strengthened columns has discrepancies between design codes. For example, Eurocode 4 (1994) does not consider explicitly reinforced concrete columns strengthened with steel caging as a composite member. The load-carrying capacity of RC strengthened member is a sum of contribution of unconfined concrete core and steel angles as:

$P_{\mathrm{u}}=0.85 f_{\mathrm{c}} b^{2}+A_{\mathrm{a}} f_{\mathrm{yl}}$

where $f_{\mathrm{yl}}$ being the design yield stress of steel angles, and $A_{\mathrm{a}}$ is the area of steel angles. A different approach to predict the load-carrying capacity of composite column, given by LRFD (American Institute of Steel Construction 1994), refers to an equivalent steel column with calculated slenderness ration. The ECP-203 (The Egyptian Code of Practice for Design and Construction of Concrete Structures (ECP203) 2007) proposes design equation for composite concrete columns. Comparing the predicted experimental results with different code limits found that the LRFD and ECP-203 had closer values to experimental results than Eurocode 4.

In this paper, a proposed model accounts for the composite action for concrete confinement and enhancement of the local buckling of steel elements. This adopted model is simplified and applicable to practical design calculus. A 
modified Eq. (14) of predicted load-carrying capacity of the strengthened RC column with steel angles and strips are adopted to account for confined concrete strength and the reduction of yield stress to incorporate local buckling of steel angles as follows:

$P_{\mathrm{u}}=m_{\mathrm{c}} f_{\mathrm{c}} b^{2}+m_{\mathrm{s}} A_{\mathrm{s}} f_{\mathrm{yl}}$

The two factors $m_{\mathrm{c}}$ and $m_{\mathrm{s}}$, presented in Eq. (15), are developed to account for confinement strength of concrete and steel cage configuration. Substituting Eq. (10) into Eq. (9), the factor $m_{c}$ can represent the concrete confinement as:

$m_{\mathrm{c}}=\frac{f_{\mathrm{cc}}}{f_{\mathrm{c}}}=1+2.15\left(\frac{2 t_{\mathrm{s}} S_{2} f_{\mathrm{yl}}}{S \cdot B}\right)$

In the case of using steel-casing, the factors $S$ and $S_{2}$ can be applied as unity in Eq. (16).

The calculus of the strength contribution of steel angles in strengthened columns adopted a loading scheme of continues beams supported by steel strips. These angels are axially loaded and laterally loaded by the confinement pressure of concrete core. The angles on the four sides of the column core are in equilibrium. In this assumption, the steel strips are acting as tension tie with small axial deformation (Campione 2012). In this case, the factor $m_{\mathrm{s}}$ represents the reduction in yield stress due to incorporation of steel strip deformation and local buckling of steel angles. This factor can be derived from substituting Eq. (3) into (4) as:

$m_{\mathrm{s}}=\frac{8.47}{2 L_{1} t_{1}} \sqrt{E_{\mathrm{r}} t_{1}\left(\alpha L_{1}\right) \frac{{ }^{3} S_{2} t_{2} E_{\mathrm{h}}}{b \cdot S}}$

In the case of strengthening method using full coverage area of steel plates the local buckling in steel plates may be occurred. In this case the factor $m_{\mathrm{s}}$ can be given as follows:

$m_{\mathrm{s}}=\frac{K \pi^{2} E_{\mathrm{s}}}{12 f_{\mathrm{yl}}\left(1-v^{2}\right)(b / t)^{2}} \quad$ for $\frac{b}{t_{1}} \geq \sqrt{\frac{3 E_{\mathrm{s}}}{f_{\mathrm{yl}}}}$

To incorporate the local buckling and as derived from Eq. (7), the value of $A_{\mathrm{s}}$ in Eq. (15) should be multiplied by correction factor equal $0.65 \sqrt{\frac{f_{\mathrm{e}}}{f_{\mathrm{yl}}}}$. If the local bulking is not occurred in the steel plates the value of $m_{\mathrm{s}}$ is equal unit.

\section{Comparison between experimental and proposed analytical models}

A computer program was developed to calculate the maximum load-carrying capacity using the adapted analytical model proposed in this paper. Through this program,

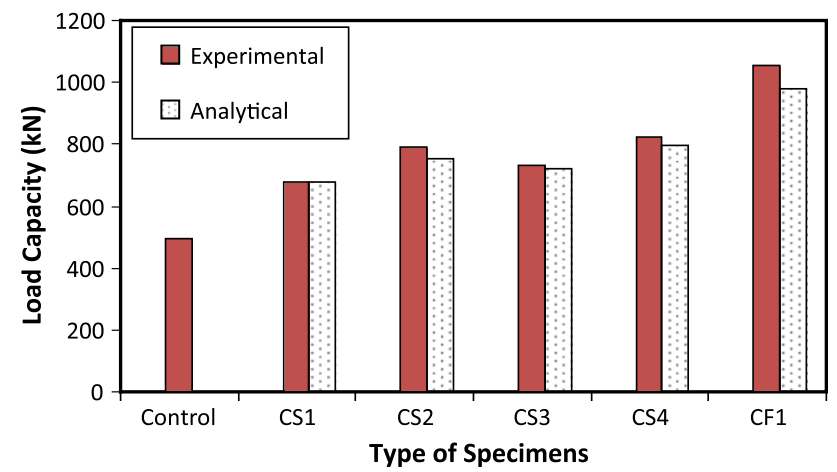

Fig. 22 Comparison between experimental observed results with analytical results

centerline dimensions of steel plates and strengthened columns were clearly addressed. Figure 22 shows a bar graph for load-carrying capacity of the strengthened columns predicted from experimental results and the calculated values extracted from the analytical equation. Comparing experimental observed results with the developed analytical model, a good agreement is obtained.

\section{Conclusions}

This paper was performed to carry out an experimental investigation for examining the enhancement of strengthened reinforced concrete columns, using steel angles and strips. Experimental work included specimens strengthened with steel-casing, compared with those strengthened with angles and strips. The analytical model, developed in this paper, was also compared with experimental observed results. This study focused on load-carrying capacity, column shortening, longitudinal strains in strips and stirrups, ductility, and stiffness factors. The experimental results clearly described the following conclusive points:

1. The increase in load-carrying capacities represented 36, 59, 48 and $66 \%$ for CS1, CS2, CS3 and CS4, respectively, as compared with the control column specimen. A comparison between the two columns strengthened using angles $40 \times 5$ and $40 \times 6 \mathrm{~mm}$, show that increasing of loading-carrying capacity by $17 \%$. For strengthened column using angles $50 \times 5$ and $50 \times 6 \mathrm{~mm}$ the load-carrying capacity was increased by $12 \%$. In these cases, the load-shortening curve is more smooth, ductile and stable. On the other hand, the percentage increase in load-carrying capacities is approximately doubled for $\mathrm{CF} 1$, as compared with the control specimen.

2. Using connected steel-casing with dowels for sample $\mathrm{CF} 2$, the load-carrying capacity increased by $9 \%$ than 
CF1 sample. The load-shortening curve of sample CF2 is also more flat and sustains higher shortening value. Observation of the connected steel-casing showed that local buckling in steel plates was reduced and higher value of confined concrete can be achieved. Extra loadcarrying capacity of connected steel-casing column could be obtained than with corresponding nonconnected one. It is evident that strengthened column of series A as well as of series B exhibit different elastic initial stiffness. This may be attributed to increase in the strengthened column initial stiffness.

3. The observed load carrying-capacity of sample CS2 is higher than that of sample CS3 by about $8 \%$, regardless of smaller angle cross sectional area. This increase in load capacity and also ductility demands may be attributed to using of thicker strips and therefore to more developed concrete confinement and higher load-carrying capacity. It can also be concluded that the increase of strip thickness and/or reduction on strip spacing is more effective than the increase of steel angle dimensions. The load-carrying capacity of CF1 is much higher than that of CS4 by about $28 \%$. It can be thus revealed that strengthened columns in series B can sustain higher shortening values than those of series $A$. The existence of dowels delays the splitting out of concrete after crushing due to buckling enhancement behavior of steel-casing. Thus, a realistic increase in the load-carrying capacity can be obtained.

4. The observed control specimen failure mode is a standard compression failure of the reinforced concrete column. It has to be observed that the column failure occurs when the steel cage is no longer to confine the concrete. The failure occurs when the steel cage, yielded with concrete between the strips, is splitting out. This failure mode occurred in series group A. In series B, a more steady failure mode of specimens CF1 and $\mathrm{CF} 2$ due to the exiting of steel-casing prevents concrete from splitting out. The failure occurs when steel-casing suffers from large deformation due to its local buckling.

5. All columns show similar pre-crushing load-strain response. The measured stirrup strain is at the same level beyond the steel strip, at the strengthened column mid-height. It could be concluded that the strain in the stirrup for the control specimen behaves as a brittle manner. This small ductility is due to regular compression failure of the control specimen. A pronounced increase in extra-confinement of strengthened columns can be observed through the experimental results. On the other hand, the stirrup strain of the other strengthened columns behaves as ductile curve due to stiffening action of the steel strip at the same level of stirrup. The stiffening action of steel strips and angles enhances the confined concrete strength and therefore delays the sudden compression failure of the columns. With increasing the strip thickness, increasing the confinement strength and the strip in this case can achieve extra strain.

6. Comparing the results of load-strain of the strengthened column specimen CS1 with CS4 shows higher loadcarrying capacity yield at higher loads and more ductile smooth curve. Increasing strip thickness results in a more confinement of concrete and yield of the strip at higher load values and thus delays the concrete splitting out concomitant with higher load values. It can be also further that the strengthened columns load gradient becomes greater than that of the control specimen, due to a marked increase in the initial stiffness.

7. A remarkable $89 \%$ increase is predicted for the ductility measure of the strengthened columns using steel-casing CF1, than in specimen CS4. It was found that the normalized cumulative stiffness of the strengthened column specimen CS4 increased by about $87 \%$ than in specimen CS1. It is predicted that the normalized cumulative stiffness of specimens CS1 and CS3 will have similar values and specimens CS2 and CS4 as well have the same value. This indicates that the strip thickness and spacing have major impact on the increase of cumulative stiffness. The dowel connected steel plates specimen $\mathrm{CF} 2$ has much cumulative stiffness higher by about $7 \%$ than the non-connected one.

8. The Eurocode analytical results conduct higher values than the experimental observed results. The LRFD code generates values closer to the experimental results due to taking the contribution of the stability analysis of steel angles into consideration. An analytical model is developed in this paper to compare the code limit with experimental observed results. The proposed model accounts for the composite action for concrete confinement and enhancement of the local buckling of steel elements. This adopted model is simplified and applicable to practical design field. A computer program was developed to calculate the load carrying capacity of the strengthened columns based on proposed analytical model. A good agreement is conducted between analytical model results and experimentally observed one.

Acknowledgments The authors would like to express their gratitude and appreciation to the National Center for Research in Construction and Housing, Egypt, for exceptional help in the experimental program. 
Open Access This article is distributed under the terms of the Creative Commons Attribution License which permits any use, distribution, and reproduction in any medium, provided the original author(s) and the source are credited.

\section{References}

Adam M, Gimenez E, Pallares F, Ivorra S (2008) Experimental study of beam-column joints in axially loaded RC columns strengthened by steel angles and Strips. Steel Compos Struct J 8:329-342

Adam M, Ivorra S, Pallares F, Gimenez E, Calderon P (2009) Axially loaded RC columns strengthened by steel casing: finite element modeling. Constr Build Mater J 161:337-348

American Concrete Institute (ACI) (1999) Building code requirements for structural concrete (ACI 318-99) and commentary. AC 318-08, Farmington Hills

American Institute of Steel Construction (1994) Manual of steel constructions: loads and resistance factor design (LRFD), 2nd edn. American Institute of Steel Construction, Chicago

Badalamenti V, Campione G, Mangiavillano M (2010) Simplified model for compressive behavior of concrete columns strengthened by steel angles and strips. Eng Mech J ASCE 136:230-238

Barga F, Gigliotte R, Laterza M (2006) Analytical stress-strain relationship for concrete confined by steel stirrups and/or FRP jackets. Struct Eng J ASCE 9:2-19

Brain U (2000) Strength of concrete filled steel box columns incorporating local buckling. ASCE J 126(3):341-352

Campione G (2008) Analytical model for high strength concrete columns with square cross-section. Struct Eng Mech J 28:295-316
Campione G (2012) Load carrying capacity of RC compressed columns strengthened with steel angles and strips. Eng Struct J 40:457-465

Campione G, Minafo G (2010) Compressive behavior of short highstrength concrete columns. Eng Struct J 32:55-66

Critek L (2001) Mathematical model of RC banded column behavior. Constr Build Mater J 15(8):351-360

Eurocode 4, EN 1994-1 (2005) Design of composite steel and composite steel structures. Part 1-1 General Rules Rules Build

Frangou M, Pilakoutas K, Dritsos S (1995) Structural repairstrengthening of RC columns. Constr Build Mater J 9(5):259-266

Li J, Gong J, Wang L (2009) Seismic behavior of corrosion-damaged reinforced concrete columns strengthened using combined carbon fiber-reinforced polymer and steel jacket. Constr Build Mater J 23(7):53-63

Mander B, Priestley M, Park R (1988) Theoretical stress-strain model for confined concrete. Struct Eng J ASCE 10:4-26

Montuori R, Piluso V (2009) Reinforced concrete columns strengthened with angles and battens subjected to eccentric load. Eng Struct J 31(2):539-550

Papia M, Russo G, Zingone G (1988) Instability of longitudinal bars in RC columns. Struct Eng J ASCE 114(2):393-419

Ramirez L, Barcena M, Urreta I, Sanchez A (1997) Efficiency of short steel jackets for strengthening of sqaure section concrete column. Constr Build Mater J 11(5):45-52

The Egyptian Code of Practice for Design and Construction of Concrete Structures (ECP203) (2007) 